\title{
Proposing a Library Consortium Model for National Development in Zimbabwe
}

\author{
Collence Takaingenhamo Chisita, University of South Africa, Pretoria, South Africa \\ iD https://orcid.org/0000-0002-7375-8627
}

\begin{abstract}
Globally, library cooperation and collaboration are transforming the scholarship landscape as academic libraries battle to survive amidst escalating costs of subscriptions. Zimbabwe is no exception to this phenomenon as evidenced by the development of local consortia for resource sharing. The main purpose of the research is to gather the views of librarians on the need for a library consortium to support national development in Zimbabwe. The researcher used a mixed method approach. Zimbabwe does not have national library consortium for nationwide access to information. Such a consortium is key to harnessing the collective buying power of member institutions to negotiate and guarantee license agreements for digital content. The study recommends a federated library consortium model built on lessons drawn from other countries. The model elevates library consortium principles of cooperation and collaboration into Zimbabwe's national development agenda.
\end{abstract}

\section{KEYWORDS}

Access to Information, Cooperation and Library Collaboration, Library Consortia, National Development, Zimbabwe

\section{INTRODUCTION}

Zimbabwe's national development blueprints commonly known as the Zimbabwe Agenda for Sustainable Socio Economic Transformation (ZIMASSET) (2013-2018) and Transitional Stabilization Programme (TSP) (October, 2018 -December, 2020) are policy documents whose success is underpinned by socio-economic factors including access to information. The documents do not explicitly state how libraries can contribute to national development. The blueprints focus more on the full exploitation and value addition to the country's abundant resources hence the need to rethink the need for a library consortium model for nation-wide access to information to support informed policy making and decision making.

The ZIMASSET (2018-2019) development blueprint was replaced by the Transitional Stabilisation Programme (TSP) (2018-2020). The TSP outlines policies, strategies and projects that guide Zimbabwe's social and economic development interventions and simultaneously targeting immediate quick-wins and laying a strong foundation for economic growth for the period 2021-2030. ZIMASSET (2018-2019) and TSP (2018-2020) are not explicit on the role of libraries, even though its success will depend on access to information.These policies resonates with the United Nations' Sustainable Development Goals (SDGs) (2015-2030). 
The SDGs serve as reference goals for the international development community for the period 2015-2030 (Le Blanc, 2015). Evans \& Steven (2012) view SDGs as a universal set of goals, targets and indicators used by the United Nations (UN) member states to frame their agendas and polices in line with the 2030 agenda. The Zimbabwe Voluntary National Review (VNR) of SDGs for the High Level Political Forum $(2017,5)$ confirmed that Zimbabwe had committed itself to implementing all the SDGs with an emphasis on SDGs 2, 3, 4, 5, 6, 7, 8, 9, 13 and 17. The realization of the SDGs is dependent on a number of factors including access to information.

Randel (2013) opined that the post-2015 settlement must harness the power of technology and information to empower citizens with choice and control over the decisions that affect their lives. The author argues that full access to information has the potential to empower the poor citizens so that they become active participants in determining how they should be governed. Dong \& Zou (2009, p1) argue that library consortia are indispensable in the drive to consolidate and integrate Chinese government agencies and state-owned businesses. The authors state that the development of library consortia in China helped the country to remain relevant and competitive especially after joining the World Trade Organisation (WTO) in 2001. Dong \& Zou $(2009,1)$ argue that the library consortia in China serve as a key pillar of a resourceful and efficient national information system useful in sustaining economic growth and the development of a world-class education system.

Csajbók, Szluka, and Vasas (2012, 335-339) highlight how library consortia contribute to Hungary's socio-economic and political renewal in the 1990's. According to the authors, the contribution of library consortia to socio-economic progress affirms the correlation between access to information and national development. The government played a significant role by supporting the development of library consortia in Hungary to support teaching, learning and research (Csajbók, Szluka, and Vasas, 2012, 335-339).

Nkondo, et.al (2014) view access to information as a pillar for national development since it helps to build an effective and efficient work force and responsible citizens. The authors perceive the library as a critical force in supporting and providing democratic access to information and hence the need to integrate it into the mainstream economy and society as a preserver and transmitter of knowledge. Namhila \& Niskala (2013) argue that the library and information service sector has been recognized globally as a critical support structure for all aspects of development. Namhila \& Niskala (2013) urge governments in developing countries to rethink the role of libraries in national development and incorporate it into the mainstream development agenda.

Read (2010) highlights how rising journal costs, especially in the scientific and technical, fields, have been staggering. When costs of subscriptions are unaffordable, then development will be affected, for example, the quality of education and research goes down and decision making at a national level will not be supported by scientific evidence. It appears cooperation is the only option for libraries if they are going to remain relevant and survive socio-economic turbulences of the twenty-first century.

The failure to align library consortia to the national development vision will result in the peripherilization of libraries thus undermining nation-wide access to information. The alignment of libraries to the national development agenda resonates well with IFLA's global vision that seeks to develop strong libraries and participatory communities to realise SDGs (IFLA, 2018) support sustainable development. Access to information is a fundamental human and constitutional right as enshrined in the constitution of Zimbabwe (2017, Article, 20). However, in order for libraries to fully contribute towards national development they should be organised and consortia is hereby proposed as a platform to build mutual relationships and capacity for national development.

Zimbabwe is not an exception to this trend as evidenced by the establishment of sector specific library consortia, for example, the Zimbabwe University Libraries Consortium (ZULC) and the College and Research Libraries Consortium (CARLC). Dong \& Zou (2009) attribute the rise of library consortia to the information explosion, escalating costs of reading material, severe budget allocations, and the increasing demand for improved service. Nfila \& Darko-Ampem (2002) state that library consortia operations encompass co-operation, co-ordination and collaboration between and amongst libraries 
for cost reduction through shared information resources. Chisita \& Dick (2018) state that a library consortium should be viewed as an association of libraries established by formal agreement, usually to improve services and mutual benefit through resource sharing. Pradhan (2014) and Farrow (2011) cite training, shared e-content, group purchasing, consultancy, cooperative collection development and a shared digital repository and storage as some of the key activities of library consortia. The authors further note that the key benefit of a consortium is the ability to speak with a single voice to funders, policymakers, publishers and service providers irrespective of the structure or purpose of the consortia. Csajbók, Szluka, \& Vasas, (2012) state that in Hungary, libraries benefit from government support in the drive to transform the economy to make Hungary globally competitive. Government funding enabled libraries through their consortia to develop library subsystems, accessible databases, building information infrastructure, enlarging collections and providing continuous professional development to support socio-economic and political development. In Zimbabwe, higher education institutions contribute towards national development through supporting human capital development by providing access to scholarly content (Chisita \& Dick, 2018).

\section{STATEMENT OF THE PROBLEM}

The realization of Zimbabwe's Vision 2020, national development goals and SDGs will depend on access to information including the political will and the commitment of Zimbabwean citizens. Yet, the value of information for development and the role of libraries and access to information are not explicitly elaborated in the vision 2020 statement. However, in order for libraries to fully contribute towards national development they should be organised and a consortium is hereby proposed as a platform to build mutual relationships and capacity to contribute to national development.

The contributions of libraries to national development is critical in the realization of national development goals in Zimbabwe. Currently, however, the national development plan is not explicit as to how libraries can contribute. Some libraries operate as single entities while only a few have organised themselves into formal consortia. The development of library consortia in Zimbabwe was a response to the desire to enhance resource sharing and improve the quality of academic library services in order to boost human capital development. While ZULC has developed into a full-fledged consortium subscribing to e-resources, the same is still lacking among CARLC members, who are yet to make optimum use of the digital era. In other words, these consortia also need to cooperate with each other to fight increasing costs. Then again, such cooperation still excludes all the country's nonacademic libraries and their users. The exclusion of other libraries from participating in the collective activities of a national library consortium will create room for separate development, and this is not positive for the country's national development trajectory which focuses on economic growth and wealth creation for the benefit of Zimbabweans. The fragmented nature of libraries as reflected in their individual modus operandi, is inconsistent with the demands of the knowledge dispensation which thrives on cooperation and collaboration. Chisita (2017) states that the overall development path of library consortia in Zimbabwe can be better envisioned when correlated with the country's national development agenda.

\section{Aims of the Study}

This study aims to explore the views of librarians in order to propose a national library consortium to support national development.

\section{Research Questions}

a) What are the views of librarians towards Zimbabwe's national development?

b) What lessons can be drawn from other countries on library consortia and national development?

c) How can library consortia contribute towards national development goals? 


\section{LITERATURE REVIEW}

The twenty-first century has seen libraries evolving new strategies to overcome numerous challenges. For example, underfunding and increasing costs of library resources are among the top challenges. Sheshadri, Shivalingaiah \& Manjunatha (2011) state that globally, the number of library consortia existing has grown steadily since the pioneering days in the last decade of the twentieth century. A number of regional consortia have emerged in recent years collaborating in sharing resources and attempting to overcome the legacy of a skewed and fragmented system of higher education (Reddy, 2000). The importance of library consortia cannot be underestimated considering the dynamics in the global information landscape. Katsikirou (2012) noted that library consortia would become even more important in the future by assisting libraries in implementing and managing the process of change. The author envisioned future library consortia focusing on conducting cooperative programs in teaching, professional development, research, publishing, educational evaluation, college finance and administration, enrichment of student life and promoting projects of educational research.

Chisita (2016) describes a library consortium as an association of independent libraries and/ or library systems established by formal agreement, usually for resource sharing. Hoang \& Genoni (2017) viewed library cooperation as an enhanced form of cooperation that serves as a strategic choice made by academic libraries internationally to improve access to a wide range of content and services. Globally, the twenty-first century has seen an increase in the number of library consortia (Csajbók, Szluka \& Vasas, 2012; Dong \& Zou, 2009; Goudar, 2013; Fresnido \&Yap, 2013; Coetsee \& Weiner, 2013; and Chisita, 2017). Library consortia have helped to support development in many countries by providing affordable access to information to enhance teaching, learning and research.

O'Neill \& Gammon (2009) explore the history of consortia and reveal that collaborative and cooperative efforts in collection development among libraries started hundreds of years ago. The authors state that later in the twentieth century, economic, social and technological changes instigated growth of consortia, and enabled libraries to work efficiently in a collaborative manner for collection building. Chisita (2017) states that library consortia in different parts of the world are in different stages of development. There are significant factors that have spurred the development of library consortia in Africa, for example but not limited to the increasing demand for higher education, the information explosion, and the proliferation of digital technologies.

Chisita (2017) cites the information explosion, the transformation of libraries into learning organizations, the proliferation of smart digital technologies, growing demands of users, developmental agendas, and increasing costs of subscriptions to e-journals library as contributory factors to the development of library consortia (Anassi \& Hussaini, 2011; Kaur, 2013; Folorunso and Folorunso, 2010, pp. 43-44; and Ossai, 2010). Digital technologies enable library consortia to shift from traditional to a modern mode of operation characterized by the use of integrated library management systems (ILS) and inter-organizational information systems (IOS). Drake (2010) pointed out that academic libraries and sequentially the educational institutions which they belong have to grapple with the problems of shrinking budgets, ever-growing user requirements, high costs of books, and subscriptions to journals (Drake, 2010). Ruan \& Qiang (2013) view the adaptation of digital technologies as an opportunity for academic libraries to derive benefit and align their resources in support of developmental programs.

Chisita (2017, p. 14) argue that if only the already powerful library sectors geared to take advantage of emerging digital technologies at the exclusion of resource starved library consortia, this might exacerbate information inequalities and miss an opportunity to connect all libraries to the country's vision for national development. The author advocates for a national consortium for nation-wide access to information. On the other hand, access to information can be improved for all Zimbabweans if the opportunity is grasped to extend the benefits of existing library consortia as widely as possible (Chisita, 2017). However, the challenge is how the existing library consortia will be harnessed to support the national development agenda. The perceptions of librarians are useful in 
building a knowledge base to support the development of a robust library consortium aligned to the national development trajectory of Zimbabwe.

Turner (2014) states that cooperation has historically been a tenet of libraries, and the history of library consortia and the activities in which they have engaged is well documented and archived. Wolf $\&$ Bloss (2000) trace the history of cooperation to the nineteenth century as reflected by cooperation between American and European higher education libraries. Cooperation amongst libraries takes many forms depending on purpose or function of library consortia. Academic libraries have over decades developed important areas for cooperation, including shared cataloging, inter-library loan and document delivery, off-site shelving facilities, joint or inclusive licensing of electronic content, and future cost containment (Neal, 2012).

$\mathrm{Pal}$ (2016) acknowledges the existence of a wide variety of library consortia organized along many different lines with plenty of models that afford opportunity libraries to cooperate and collaborate for enhanced access to information. Models are designed to support national development about higher education, research and development and democratic participation of citizens in national development programs. The development of library consortia models in the United Kingdom has been influenced by similar factors as those found in Australia, the United States and Africa (Weber, 2006, pp. 382-393). In developed countries, the state plays a critical role in supporting library consortia development as highlighted below.

Chisita (2017, p.57) describes how the library consortia development in China was supported by the national government through national policies that prioritized library development. Consortium building often expresses itself in resource sharing even though it can also be used to plan for sharing bibliographic and full text databases and other services in each of the libraries that are part of the consortium in China (Zhang \& Gourley, 2006). Collaboration and sharing of commitments and facilities between libraries is a logical development especially under the strained financial circumstances in which most libraries operate.

Csajbók, Szluka, and Vasas, (2012, pp. 335-339) highlighted that the development of library consortia in Hungary gathered momentum after the collapse of communism in the 1990's. Such consortia include those organised around specific vendors such as EBSCO and ProQuest and those supported by the national government. Csajbók, Szluka, and Vasas, (2012, pp. 335-339) state that at the time of regime change the government realised that economic expansion could only be possible through human capital development. This resulted in increased funding from the government in the drive to transform the economy and make Hungary globally competitive. Government funding enabled libraries to develop library subsystems, accessible databases, building information infrastructure, enlarging collections and continuous professional development.

India is an Asian country that provides classic examples of the challenges and opportunities of developing library consortia. Mahajan (2005) states that India has over 400 universities and institutions of national importance and 18,600 colleges that provide higher education in all disciplines. Mahajan (2005) describes how Indian universities were struggling to maintain subscriptions to even core journals due to ever increasing costs of journal subscription. The development of library consortia was interpreted as a means to overcome the escalation of the cost of scholarly material, the information explosion and emerging information needs of users. Goudar (2013) argues that development of library consortia in India was precipitated by the escalating prices of journals, the geometric growth of scholarly publishing and uncertain foreign exchange rates that put already shrinking budgets of Indian libraries in steep decline. In an endeavor to support research activities throughout the country and to avoid duplication of activities, the government of India launched a national information system called the National Information System for Science and Technology (NISSAT) in 1977 (Chauhan \& Mahajan, 2013). NISSAT supported and sponsored resource-sharing activities by establishing library networks and consortia in India.

Sheshadri, Shivalingaiah \& Manjunatha (2011) note how the Networked Library Consortia of the United Arab Emirates (UAE) has provided local libraries with an opportunity to conduct library 
activities effectively and economically with a united voice in various activities. Libraries are involved in inter-library lending (ILL), collaborative development of resources, pooling of journals, and subscriptions to journals and databases, union catalog of resources and labor training and centralized negotiations with database vendors (Sheshadri, Shivalingaiah \& Manjunatha, 2011). Despite different levels of development, the United Arab Emirates (UAR), India and the Philippines are utilizing ICTs to network different types of libraries to provide seamless access to electronic content in support of learning, teaching and research (Chisita, 2017).

\section{Development of Library Consortia in Africa}

The development of libraries and library consortia in Africa are inseparable issues because the former provides the basis for the development of the latter. Given the potential value of library consortia to address these challenges, there have been external efforts to promote their development. The Electronic Information for Libraries (EIFL) and the Network for the availability of scientific publications (INASP) are key development partners that have contributed to the growth of library consortia in Africa, Zimbabwe included. They have focused on building capacity to use, manage and communicate research information (Mapulanga, 2012).

In West Africa, the development of the Consortium of Academic and Research Libraries (CARLIGH) in 2014 and the Nigerian University Libraries Consortium (NULIC) formed in 2011 in Nigeria. Chisita (2017) noted that the challenges that affect library consortia in West Africa are similar to those affecting library consortia in other regions of Africa.

Otando (2011a) stated that libraries in Kenya came together in 2002 to create the Kenya Libraries and Information Services Consortium (KLISC). The development KLISC was also supported by INASP with its commitment to fund electronic journals sourced through the first phase of the PERI and the drive towards self-sustenance (Otando, 2012b). The same trend is observable in the development of library consortia in other African countries as highlighted in the next section.

\section{Library Development in Southern Africa}

Mwiyeriwa \& Ngwira (2003) state that Malawi established its own Library and Information Consortium (MALICO) in 2002. Shafika (2007) states that MALICO was established as a consortium of organizations that combine talents and resources to promote and deliver library and information services for Malawi and the global community. Its members participate in the acquisition and delivery of relevant electronic resources in contributing to the national development agenda through supporting education and research.

Chisita (2017) describes how the development of library consortia in Malawi has also been leveraged through support from EIFL, but the critical challenge is the lack of support from the state. The author recommends that library consortia should go beyond resource sharing to consider "infopreneurship" to achieve sustainability. Even though South Africa has a better record of sustainability, it still faces challenges that are common to other consortia in Africa, for example, higher costs of internet connectivity.

Library consortia in South Africa have contributed to the political, social, and economic transformation in South Africa through providing equal opportunities for all in South Africa (Coetsee $\&$ Weiner, 2013). Thomas and Fourie (2007) and Taole (2009) noted that regional library consortia in South Africa promoted resource sharing through purchasing common library systems, joint purchasing of electronic resources and licensing agreements.

Ndlovu (2011) traces the origins of ZULC to February 2000, when the various university libraries conglomerated to discuss ways of cooperating as one group. He states that after discussions, a funding proposal was written to the Open Society Institute of Southern Africa (OSISA) for the formation of a university library consortia. This marked the genesis of the first sectoral library consortia representing universities and college and research libraries in Zimbabwe. Sahu (2006) stated that the conventional model of scholarly communication, based on journal publication, has been unsuccessful 
in democratizing access to information accessible and usable especially for the developing world due to high subscription fees.

Africa, including Zimbabwe, has not been spared from the effects of high subscription fees for scholarly communication that are beyond the reach of many institutions (Kusekwa \& Mushowani, 2013). Chisita (2017) opines that the development of library consortia in Zimbabwe is characterized moreover by a sectoral model initially supported through EIFL and external development partners. The author highlights the need for a new model that will not just extend the benefits of library cooperation and development to other types of libraries, but that will underpin the larger goals of national development and not just those of the higher education sector. Resource sharing activities are critical for the survival of libraries at a time when resources are becoming scarce. Pradhan (2014) suggested a three-pronged approach to boost resource sharing activities: strengthening and reengineering existing consortia; developing library consortia networks; and linking consortia based networks to realize networking of libraries for development. Such an initiative will result in economies of scale, accelerate research and contribute towards national development.

\section{RESEARCH METHODOLOGY}

The researcher used a mixed methods approach. Data was collected through questionnaires and interviews. The researcher tested the data collection tools on institutions in Harare. The research sites for this study are academic libraries subscribing to the Zimbabwe University Libraries Consortium (ZULC) and the College and Research Libraries Consortia (CARLC). Through purposeful sampling the researcher selected ten (10) institutions from ZULC and five (5) from CARLC as research sites. The sample for the questionnaire and interviews was drawn from assistant librarians from ZULC and CARLC. The researcher sampled 22 assistant librarians from ZULC and 9 from CARLC. The researcher interviewed 10 heads of libraries from ZULC (5) and CARLC (5). The assistant librarians are actively involved in consortia committee activities. They comprehend issues pertaining to the consortium and they also understand user needs. The heads of libraries were targeted because they are responsible for policy issues and strategic planning regarding their institutions' participation in consortium activities. The researcher used a purposeful sampling technique because the sampling procedure provided for the choice of informants was because of the special qualities they possess. Such a technique affords the researcher the freedom to choose the informants who will be able to provide the information because of their knowledge and experience (Flick, 2018). Yin (2011, 311) defined a purposeful sampling as "the selection of participants or sources of data to be used in a study, based on their anticipated richness and relevance of information in relation to the study's research questions."

The research sites were identified through a list from the Zimbabwe Library Association (ZIMLA) and through purposeful sampling techniques. Purposeful sampling is one technique often employed in qualitative investigation. Creswell \& Creswell (2017) and Maxwell (2012) viewed a purposeful sample as the strategy in which a particular settings, persons or events are deliberately selected to provide essential information that cannot be obtained from other sources. The population was drawn from librarians who are involved in consortia activities. Data was collected through a literature review, questionnaires, and interviews. The researcher utilized a purposeful sampling technique in order to focus on specific characteristics of a population that are of interest, and will make it possible for the researcher to answer research questions.

\section{ANALYSIS AND INTERPRETATION OF DATA}

\section{Location and Number of Responses}

The researcher distributed nine (9) questionnaires to five (5) CARLC member institutions of which three (3) are located in the different provinces of Harare. Academic institutions subscribing to CARLC 
focus on Technical and Vocational education (TVET). The institutions offer tertiary courses in various disciplines. Although CARLC members are located in the ten (10) provinces of Zimbabwe, they are concentrated in Harare province since it is the capital city, and it has a higher concentration of higher and tertiary education institutions.

\section{Indicate the Reasons Why Your Institution Subscribes to a Library Consortium}

This question sought to generate data on the reasons why institutions joined library consortium. Responses to the questions follow below.

The researcher sought to find out whether respondents understood the reasons why their institution subscribed to a library consortium and how library consortia can contribute to national development. The majority of respondents from ZULC $(n=20)$ cited increasing costs of subscriptions as a primary reason for joining and subscribing to a library consortium. Documentary evidence on socio-economic conditions between 1999 and 2005 confirm the impact of Economic Structural Adjustments (ESAP) on social services (NUST Vice Chancellors Report, 2011; Makoni, 2000). A literature review and responses from the interviews confirmed that ZULC was able to negotiate with UNESCO to use coupons as legal tender to purchase electronic journals during the hyper-inflationary period between 2007 and 2009 (Kadyamatimba and Tapfuma, 2014; Country Report, 2009). However, the rate for purchasing these coupons continued to escalate, and made it difficult to sustain subscriptions to PERI resources (Country Report, 2009). This complex and challenging scenario affected learning, teaching and research.

The majority of CARLC respondents $(n=8)$ also cited compelling reasons relating to rising costs of subscriptions viz-a-viz and dwindling budgets as key drivers spurring library cooperation for national development. Other reasons cited included, the growing demands by users considering the new courses and changes in the curriculum, the information explosion and a desire to keep abreast of current discourse in scholarly communication provision of discounts and subsidies. The responses from interviews revealed that they did not really understand the concept of library consortium and how they could benefit from it. The respondents highlighted the challenges of adjusting to a new curriculum or new discipline amidst dwindling budgets. They cited the government's emphasis on Science Technology Engineering and Mathematics (STEM) from 2016 onwards as a factor justifying the need for collaboration among libraries. The respondents indicated that collaboration would help libraries to share resources in order to build capacity for education and research.

\section{Which Type of Library Consortia Models are Suitable for Zimbabwe?}

Zimbabwe currently has a sectoral (academic) consortia model, and this question sought to discover the respondents' level of understanding of the kinds of models, as well as consensus on the model most suitable for the future of Zimbabwe. Respondents from ZULC chose several consortium models. The multi-type model had 22.7\% $(\mathrm{n}=5) ; 36.3 \%(\mathrm{n}=8)$ indicated a preference for the sectoral model; $9.01 \%(n=2)$ preferred regional, $22.7 \%(n=5)$ preferred national, 9.29\% $(n=2)$ preferred all of the above except regional. The multi-type and national library consortium model received a high response rate $(22.7 \%, \mathrm{n}=5)$. The respondents indicated that Zimbabwe's different types of libraries would benefit from an inclusive model that has a national scope. Currently, only academic libraries are involved in formal library consortia activities. Responses from the interview showed preference for a national library since it ideal for providing nation-wide access to information for national development. Responses to the questionnaire and interview concurred that such a model would best suit and fulfill the interests of all the libraries in Zimbabwe and contribute to the country's national development programs (Figure 1).

ZULC respondents, 36.3\% $(n=8)$ indicated they preferred a sectoral library model. In the interviews they explained that if different types of libraries organize themselves into sector-specific consortia, this could be a basis for developing a national library consortium. The respondents felt that there was need for thorough groundwork before embarking on developing a national consortium. 


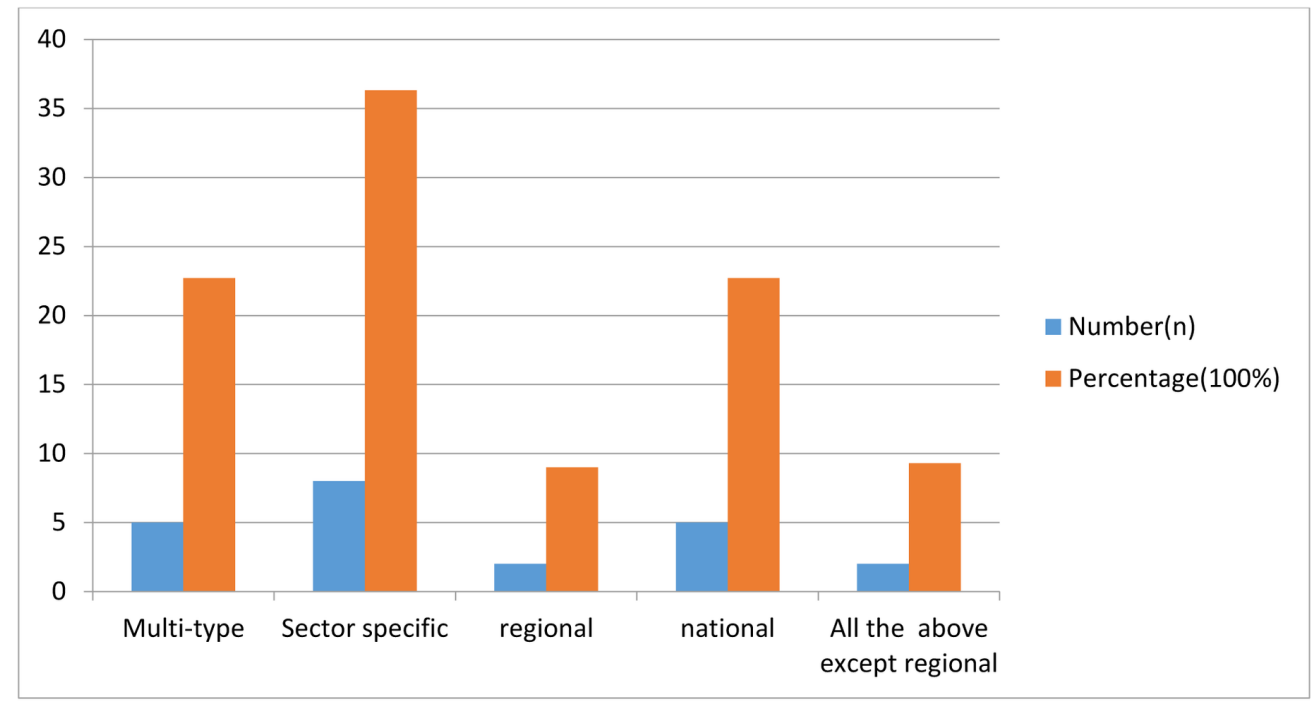

The respondents preference for all types of models was $9.09 \%(n=2)$, namely multi-type, sectoral, regional and national library consortia. It is clear that there was concurrence that all types of libraries should benefit from resource sharing, but this is not given the clearest expression in the choice of consortium model to achieve this goal.

Unsurprisingly, a similar pattern of responses was found among CARLC respondents whereby $22.2 \%(\mathrm{n}=2)$ indicated the multi-type model as the preferred choice. The sectoral library consortia model had $55.6 \%(n=5)$ and $22.2 \%(n=2)$ indicated a preference for a national library consortia model. The high response rate in favor of a sector-specific model among CARLC respondents is an affirmation to strengthen their consortium in all aspects viz - a viz technological changes in the library and information sector (Figure 2).

\section{How Can Consortium Development be Accelerated to Contribute to Zimbabwe's National Development Programs?}

This open-ended question yielded an overwhelming consensus that learning from the successes and challenges of consortia in other parts of the world would accelerate development, and provide useful lessons for Zimbabwe. ZULC respondents $(n=16)$ indicated there was need to develop and strengthen sector-specific library consortia before embarking on a project to develop a national library consortium relatively similar to the South African National Library and Information Consortium (SANLiC). This consortium is registered as a not-for-profit company with a governance and management structure, appointed directors, chairperson, deputy chairperson, treasurer, and the Director responsible for the strategic direction and implementation of the strategic plan. Respondents $(22.7 \%)(n=5)$ from ZULC indicated that the already existing library consortia should assist other library sectors to establish their own consortia. They indicated that it would be easier to develop a national consortium that amalgamates sector specific consortia. The respondents indicated that there was need for an organizing committee 


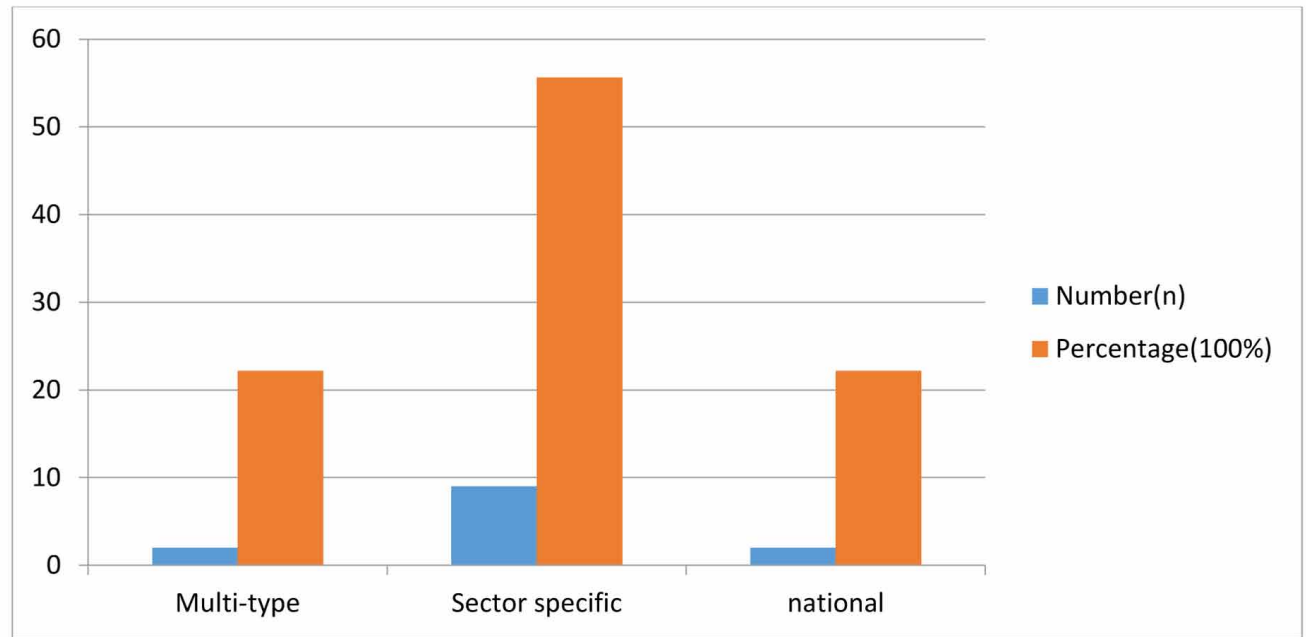

composed of representation from various sectors to spearhead the establishment of a national library consortium for Zimbabwe in order to realize developmental goals.

\section{Summary Analysis of Interview Responses on Key Themes}

The researcher used a semi-structured interview schedule. The researcher interviewed ten librarians occupying the highest ranks in the samples - ZULC (50\%, $n=5)$ and CARLC (50\%, n=5). These individuals served as library consortia board members. The response to the interviews substantiated the questionnaire, and documentary data, adding weight to the overall analysis and interpretation. Interviewees were asked to comment on five (5) themes, but other follow-up questions helped in probing for more detail. The analysis will present each theme accompanied by the responses and ensuing discussion.

\section{Consortia and Zimbabwe's National Development Programs}

ZULC interviewees believe that their members should justify their existence beyond resource sharing. They advocated for radical cooperation and collaboration that transcends e-journal subscription by exploring shared licensing, storage, and continuous staff development. They also highlighted the need for innovative projects, for example, lobbying for a network of library consortia in Zimbabwe. ZULC's strategic concerns are about governance, sustainable funding, capacity building, technological development, changing user needs, collaboration and partnerships, fundraising, and the socio-economic development (ZULC, 2016).

CARLC interviewees indicated the urgent need to develop their consortium for the benefit of member libraries. They looked forward to increased activity among CARLC. They also expressed optimism about the proposed national library consortium for Zimbabwe.

ZULC and CARLC interviewees spoke highly of how the proposed national library consortium would address the challenges facing libraries in Zimbabwe. They hinted on the need for the proposed library consortium to be aligned to the national development programs. There was reasonable 
consensus that much can be learnt from other countries on how to develop a library consortium model for nationwide access to information.

\section{How Can the Lessons Learned from Consortia in Other Countries be Integrated into a Model to Support Zimbabwe's National Development Agenda?}

Zimbabwe can draw lessons from both developed and developing countries. A suitable eclectic library consortium model will be constituted of a proper structure, reliable finance, effective governance, well-defined functions, and a special orientation towards national development.

\section{Structure of the Proposed Library Consortium Model for Zimbabwe}

The structure will be constituted of a chairperson, governing body and professional committees and general membership from all types of libraries in Zimbabwe. This structure will work towards extending the benefits of cooperation to all libraries in Zimbabwe.

\section{Finance}

The proposed model adopted should provide for local needs without undermining standards. The support from the government will contribute to Zimbabwe's library consortia on a long-term basis. While international support is critical, it does not provide long-term solutions and financial sustainability. Governments can support library consortia development through the development of a national information infrastructure to enable easy and convenient access to the internet. It can also provide grants, as is the case with China, the United Arab Emirates, India, and South Africa. This can also be achieved through public and private sector partnerships. Infrastructural development will facilitate a national information system to improve access to information. This will involve ICT experts to maintain system including links and preventing link rots. State funding is crucial to sustain the ongoing activities of the consortium, and project funding will be useful for special needs, upgrading, and training. The state should therefore consider its long-term investment to target the achievement of national development goals.

\section{Governance}

Effective governance is critical for the success of any organization. Good governance should ultimately translate into quality service delivery. The proposed model will have systems that will eliminate deficiencies relating to human and institutional capacity. Effective structures of governance consisting of a small steering committee consisting of representatives of member institutions and government, advisory board and a law librarian will provide direction. Working groups will be formed to address key issues, for example, the selection of credible databases, technical issues, user services, metadata standards and protocols.

\section{Functions}

Lessons drawn from other countries within and outside Africa emphasize the need for library consortia to fulfil a number of key functions that include licensing, negotiations and access, collection development, providing user support and technical services, promoting compliance with standards, and education and training. These functions are important because they are the raison d'être for the existence of the consortium. These functions require a strong commitment to mission, strategic direction, and payment of subscriptions by members.

\section{Special Features}

The special features of the proposed federated model are its obligation to the Zimbabwe's national development agenda, nation-wide access to information and e-content licensing. The proposed 
federated library consortium can connect the country's libraries with users, relevant government departments and other development partners to widen access to information (Figure 3-4).

\section{CONCLUSION}

The proposed model effectively echoes and uplifts the fundamental library consortium principles of cooperation and sharing onto the national development stage. The responses about national development have been given meticulous and intellectual expression in this model. The study has shown that there is need for a national library consortium which will provide for the needs of all types of libraries. Through continuous engagement, the proposed library consortium model has the potential to provide for the growing and dynamic needs of Zimbabwe highlighted by the research findings. The vision of the proposed library consortium reflects a far-reaching commitment to promoting for nation-wide access to information for all institutions.

\section{GENERAL RECOMMENDATIONS}

The study makes the following recommendations:

- The proposed library consortium model should be aligned with the national development goals;

- There is need to engage key stakeholders to initiate dialogue at the highest government and professional levels about the proposed library consortium model;

- A framework and a time-line for the actualization of set targets and assigned responsibilities should be produced, and monitored;

- There should be continuous debate on the proposed consortium;

- The structures for connecting the library consortium are necessary to ensure effective and successful operationalization of the proposed model; and

- There is a need to engage international and regional library organizations. 
Figure 3. Outer layer of the proposed library consortium model for Zimbabwe

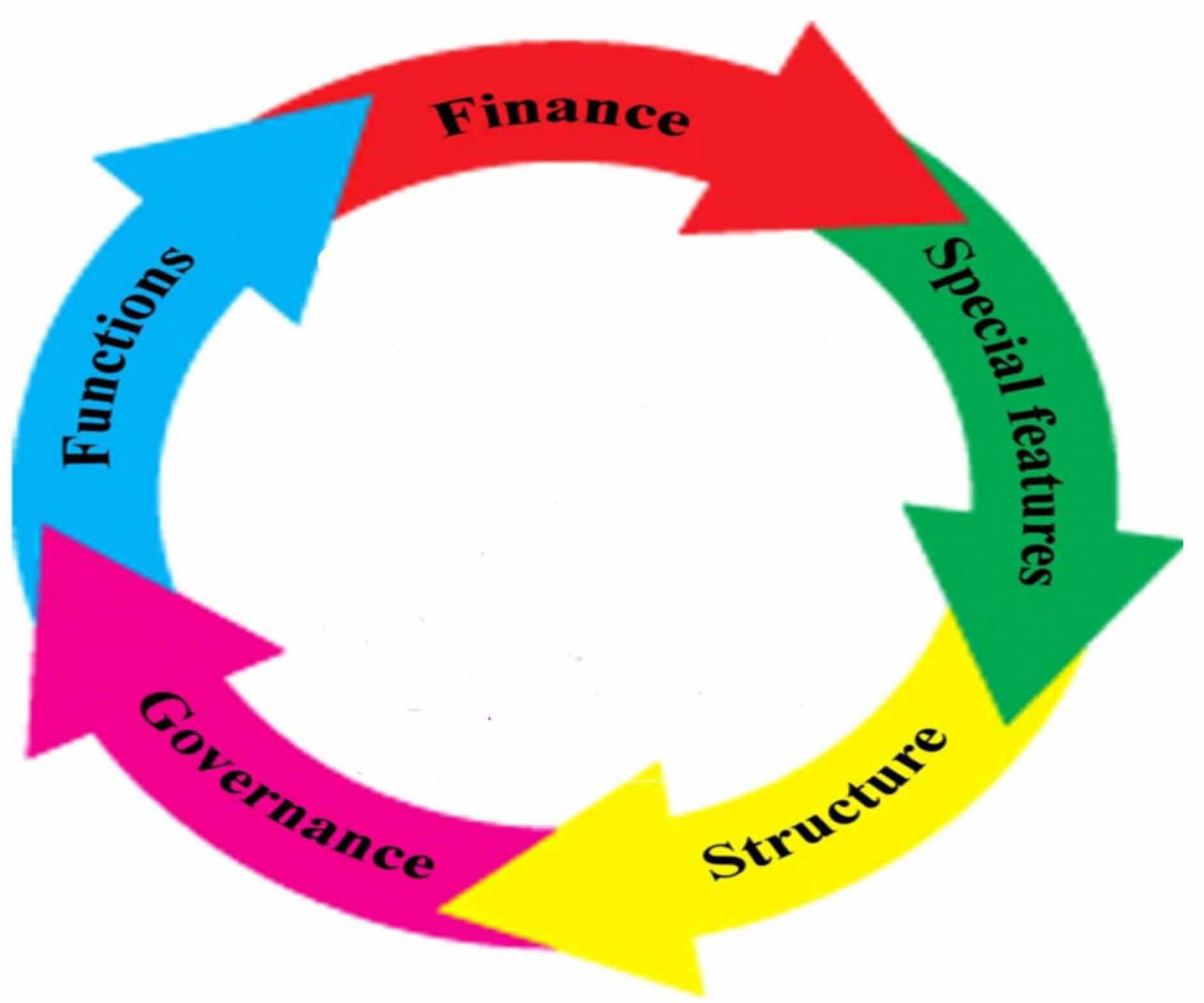




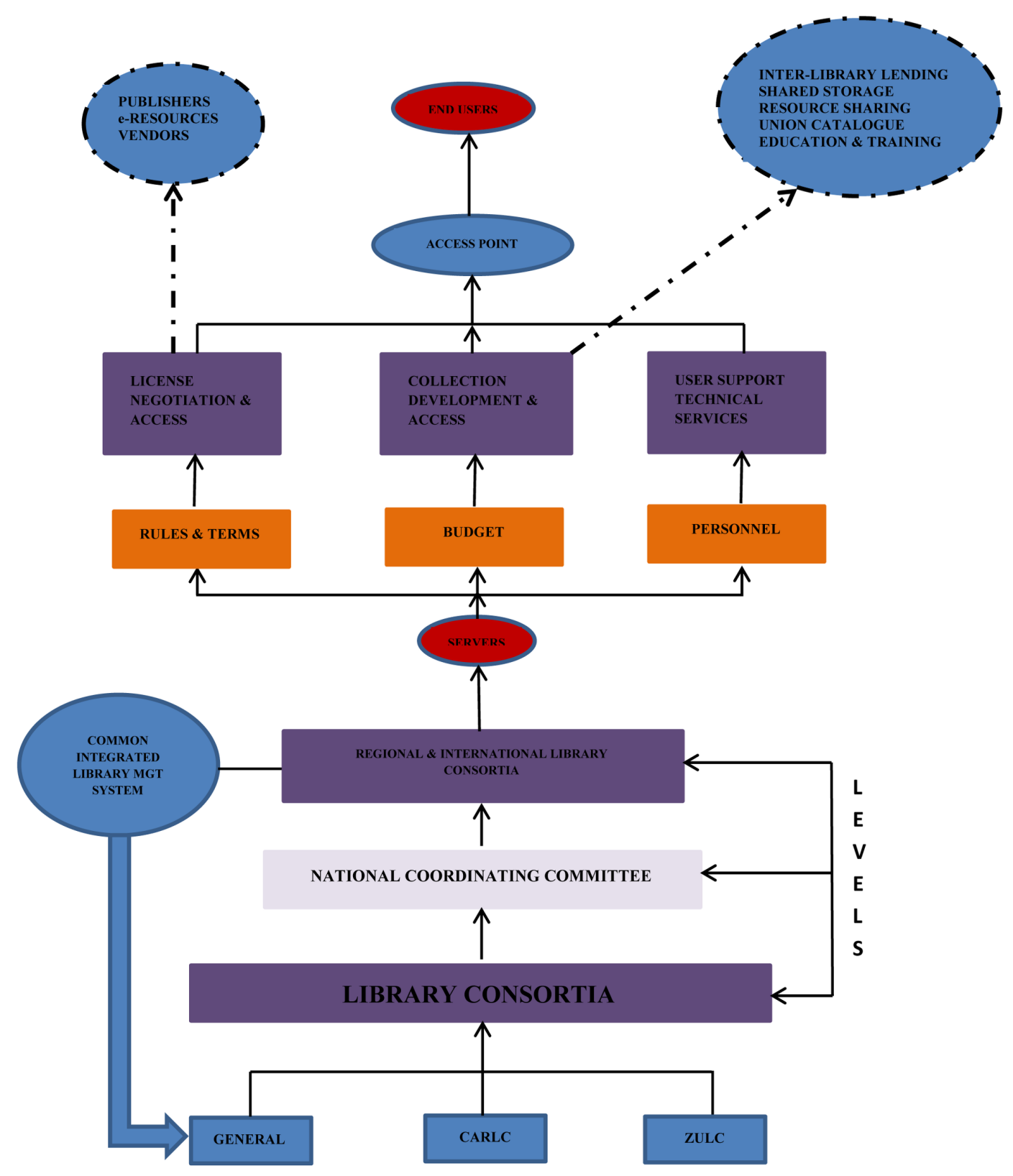




\section{REFERENCES}

Anasi, S., \& Hussaini, A. (2012). Resource sharing challenges and prospects in Nigerian university libraries. Interlending \& Document Supply, 40(3), 156-162. doi:10.1108/02641611211258235

Chauhan, S. K., \& Mahajan, P. (2013). Library consortia in India with special reference to UGC-Infonet digital library consortium. The International Information \& Library Review, 45(3-4), 127-138. doi:10.1080/105723 17.2013.10766380

Chisita, C. T. (2017). Library consortia and Zimbabwe's national development agenda: Librarians' views on constructing a suitable model (Doctoral dissertation, University of Pretoria). https://repository.up.ac.za/ handle/2263/62248

Chisita, C. T., \& Dick, A. (2018). Library cooperation in Zimbabwe: In search of a suitable model to underpin national development. The Electronic Library, 36(4), 633-649. doi:10.1108/EL-04-2017-0072

Coetsee, T., \& Weiner, S. A. (2013). Key professional principles for South African academic librarians. Mousaion, 31(3), 110-126.

Creswell, J. W., \& Creswell, J. D. (2017). Research design: Qualitative, quantitative, and mixed methods approaches. Sage Publications.

Csajbók, E., Szluka, P., \& Vasas, L. (2012). Library consortia in Hungary. Journal of Academic Librarianship, 38(6), 335-339. doi:10.1016/j.acalib.2012.09.012

Dong, E. X., \& Zou, T. J. (2009). Library Consortia in China. LIBRES Library and Information Science Research Electronic Journal, 19(1).

Drake, M. A. (2010). Academic library challenges. Searcher (Medford, N.J.), 18(9).

Evans, A., \& Steven, D. (2012). Sustainable Development Goals: A Useful Outcome from Rio+ 20? Centre on International Cooperation. http://www.globaldashboard.org/wp-content/uploads/SDGs-briefing1.pdf

Farrow, E. (2011). We are all in this together: Library consortia cost sharing. https://www.inasp.info/sites/ default/files/2018-together.pdf

Flick, U. (2018). An introduction to qualitative research. Sage (Atlanta, Ga.).

Fresnido, A. M. B., \& Yap, J. M. (2014). Academic library consortia in the Philippines: Hanging in the balance. Library Management, 35(1), 15-36. doi:10.1108/LM-04-2013-0028

Goudar, I. R. N., \& Poornima, N. (2004). Emerging pricing models for E-Journals Consortia and Indian initiatives. Proceedings of the International Conference on Digital Libraries (ICDL), 333-335.

Hoang, T. T., \& Genoni, P. (2017). The Prospects for Vietnamese Academic Library Consortia: Results of a Survey. Libri, 67(1), 15-33. doi:10.1515/libri-2016-0050

IFLA. (2015). Libraries and national development plans. https://www.ifla.org/files/assets/hq/topics/librariesdevelopment/documents/libraries-national-development-plans.pdf

Kaur, H. (2013). Local, regional and global collaborative efforts amidst the global financial crisis: Consortia. International Journal of Library and Information Science, 5(8), 235-239.

Kusekwa, L., \& Mushowani. (2014). The open access landscape in Zimbabwe: the case of university libraries in ZULC. Library Hi Tech, 32(1), 69-82.

Le Blanc, D. (2015). Towards integration at last? The sustainable development goals as a network of targets. Sustainable Development, 23(3), 176-187. doi:10.1002/sd.1582

Mahajan, P. (2005). Academic Libraries in India: a Present-Day Scenario. Library Philosophy and Practice, 8(1).

Maxwell, J. A. (2012). Qualitative research design: An interactive approach (Vol. 41). Sage publications.

Mwiyeriwa, S. S., \& Ngwira, M. E. (2003). A Malawi library consortium: Learning as we go. INASP Newsletter, 1(1), 9-11. 
Namhila, E. N., \& Niskala, R. (2013). Libraries supporting national development goals in Namibia. IFLA Journal, 39(1), 58-69. doi:10.1177/0340035212473428

Ndlovu, S. N. (2011, August). Skating on thin ice: the resilience of the Zimbabwean Libraries during the decade 2000 to 2010. In World library information congress 77th IFLA conference (pp. 13-18). Puertorico. http:// conference.ifla.org/past/ifla77/113-ndlovu-en.pdf

Neal, J. G. (2012). Parabiosis and particularism: Redefining the 21 st century collection. In Libraries at Webscale. Dublin, OH: OCLC. https://www.oclc.org/ca/en/reports/webscale/default.htm

Nfila, R. B., \& Darko-Ampem, K. (2002). Developments in academic library consortia from the 1960s through to 2000: A review of the literature. Library Management, 23(4-5), 203-212. doi:10.1108/01435120210429934

Nwalo, K.I.N. (2008). Consortium building for the effectiveness and sustainability of academic and research library services in the information age: Nigeria in perspective. Journal of Social and Cultural Studies, 11(1), 9-16.

Ossai, N. B. (2010). Consortia Building among Libraries in Africa, and the Nigerian Experience. Collaborative Librarianship, 2(2), 2. doi:10.29087/2010.2.2.07

Otando, R. M. (2011b). Building institutional repositories in KLISC member institutions in Kenya: Current status and emerging challenges. Proceedings of the 14th International Symposium on Electronic Theses and Dissertations. dl.cs.uct.ac.za/conferences/etd2011/papers/etd2011_otando.pdf

Otando, R. M. (2012a). Building Institutional Repositories in KLISC Member Institutions in Kenya. INASP Newsletter, 47, 4.

Pal, J. K. (2016). Evolution of Mutual Efforts in Libraries: The Consortia Boom. SRELS Journal of Information Management, 53(4), 317-321. doi:10.17821/srels/2016/v53i4/84262

Pradhan, S. (2014). Library and information science education in India: Perspectives and challenges. International Research. Journal of Library and Information Science, 4(1).

Randel, J. (2013). Why access to information needs to be central to the debate on poverty. The Guardian. www. theguardian.com/global-development-professionals-network/2013/jan/18/mdgs-poverty-eradication-informationaccess

Read, K. (2010). Collective voice for collective good: Library consortia, open access, and the future of scholarly communication. OLA Quarterly, 16(3), 23-28. doi:10.7710/1093-7374.1294

Ruan, L., \& Qiang, Z. (2013). The Role of Information Technology in Academic Libraries' Resource Sharing in Western China. Library Trends, 62(1), 180-204. doi:10.1353/lib.2013.0027

Sheshadri, K. N., Manjunatha, K., Shivalingaiah, D., \& Radhakrishnan, N. (2011). Library consortium, resource sharing and networking in United Arab Emirates-a study. Library Philosophy and Practice, 1.

Sheshadri, K. N., Shivalingaiah, D., \& Manjunatha, K. (2011). Library Consortia in United Arab Emirates: An Opinion Survey. Paper presented at Asia-Pacific Conference on Library and Information Education and Practice 2011 (ALIEP2011) held at Pullman Putrajaya Lakeside, Malaysia.

The constitution of Zimbabwe as amended to no.16 of 20 April 2000

Transitional Stabilisation Programme: Reforms Agenda. (2020). https://kubatana.net/wp-content/uploads/2018/10/ Transitional-Stabilisation-Programme-Final.pdf

Turner, C. N. (2014). E-resource acquisitions in academic library consortia. Library Resources \& Technical Services, 58(1), 33-48. doi:10.5860/lrts.58n1.33

Wolf, M. T., \& Bloss, M. E. (2013) Creating New Strategies for Cooperative Collection Development Collection Management. Papers from Aberdeen Conference.

Yin, R. K. (2011). Qualitative research from start to finish. Guilford Press.

Zengeya, M. A. (2012). A Critical Analysis of the One Hundred Years of Growth and Development of Technical and Vocational Education Policy in Zimbabwe: 1890 - 1990 (Unpublished doctoral thesis). Department of Adult Education University of Zimbabwe. 
Collence Takaingenhamo Chisita is a Research Fellow based at the University of South Africa in the Department of Information Science, College of Human Sciences. Chisita is also a lecturer in the area of Library Science, Information Retrieval, Digital Diplomatics, and Forensic Bibliographic reconstruction. Chisita completed PhD in Information Sciences focusing on library consortium models for Zimbabwe. Chisita is a renowned writer and speaker who has presented papers at various fora including Euro Africa Partnership for Research in ICT's, Promoting African European Research Infrastructure Partnerships (PAERIP), IFLA, among others. He has also worked with Ubuntunet Alliance and other regional and international NRENS. 